\title{
A NEW FROG OF THE ELEUTHERODACTYLUS ABBOTTI SPECIES GROUP (ANURA: ELEUTHERODACTYLIDAE) FROM HISPANIOLA, WITH BIOACOUSTIC AND TAXONOMIC COMMENTS ON OTHER SPECIES
}

\section{Nueva rana del grupo de especies Eleutherodactylus abbotti (Anura: Eleutherodactylidae) de la Hispaniola, con comentarios bioacústicos y taxonómicos de otras especies}

\author{
Luis M. Díaz¹, Sixto J. Incháustegui², Cristian Marte³, Gunther Köhler", \\ Antonio Cádiz ${ }^{5}$ and Marcos Rodríguez ${ }^{2}$
}

\begin{abstract}
${ }^{1}$ Museo Nacional de Historia Natural de Cuba. Obispo \#61, esquina Oficios, Plaza de Armas, Habana Vieja. lmdiaz@mnhnc.inf.cu.

${ }^{2}$ Grupo Jaragua, El Vergel \#33, El Vergel, Santo Domingo, República Dominicana. sixtojinchaustegui@yahoo.com

${ }^{3}$ Museo Nacional de Historia Natural "Prof. Eugenio de Jesús Marcano", Calle César Nicolás Pensón,

Plaza de la Cultura, Santo Domingo, República Dominicana. c.marte@mnhn.gov.do.

${ }^{4}$ Senckenberg, Forschungsinstitut und Naturmuseum Frankfurt, Senckenberganlage 25,

60325 Frankfurt a.M., Germany. gkoehler@senckenberg.de.

${ }^{5}$ Research Scientist Department of Biology, Queens College, City University of New York, 65-30 Kissena Blvd, Flushing, NY 11367, U.S.A. tonycadiz1980@gmail.com.
\end{abstract}

\begin{abstract}
A new species of frog, Eleutherodactylus geitonos sp. nov., is described from the southeastern slope of the Cordillera Central, Dominican Republic. The new frog is closely related to E. haitianus and both species share a small size. They differ in some morphological proportions and other external features, coloration, advertisement calls and DNA sequences of the 16S rRNA gene. Morphological and bioacoustic comparisons with other species in the $E$. abbotti species group are also provided. Our preliminary genetic data suggest that the taxonomic status of E. neodreptus (a synonym of E. audanti) and E. melatrigonum need to be re-evaluated.
\end{abstract}

Keywords: Amphibia, taxonomy, West Indies, Dominican Republic, subgenus Eleutherodactylus, Terrarana.

\section{RESUMEN}

Se describe una especie nueva de rana, Eleutherodactylus geitonos sp. nov., de la ladera sureste de la Cordillera Central, República Dominicana. Esta especie está cercanamente emparentada con E. haitianus, con la cual comparte una talla pequeña. Ambas especies se diferencian en algunas características y proporciones morfológicas, llamadas de anuncio, coloración y las secuencias del gen $16 \mathrm{~S}$ ARNr. Son abordadas las comparaciones morfológicas y bioacústicas con otras especies del grupo E. abbotti. La filogenia obtenida a partir de datos genéticos preliminares sugieren que el estatus taxonómico de E. neodreptus (sinónimo de E. audanti) y E. melatrigonum requiere ser reevaluado.

Palabras clave: Amphibia, taxonomía, Antillas Mayores, República Dominicana, subgénero Eleutherodactylus, Terrarana. 


\section{INTRODUCTION}

Amphibians of Hispaniola comprise 73 species, and $59 \%$ of this fauna inhabit the Dominican Republic. The Eleutherodactylus abbotti species group belongs to the subgenus Eleutherodactylus and is represented by seven species (sensu Hedges et al., 2008): E. abbotti, E. audanti, E. haitianus, E. melatrigonum, E. notidodes, E. parabates and E. pituinus. Until the last taxonomic review by Hedges et al. (2008), E. audanti was for a long time considered to be a polytypic species, with one subspecies restricted to each of the main mountain ranges of Hispaniola: E. a. audanti Cochran, 1934 (Massif de la Hotte, Massif de la Selle, Sierra de Bahoruco), E. a. melatrigonum Schwartz, 1966 (Cordillera Central), and E. a. notidodes Schwartz, 1966 (Sierra de Neiba). Eleutherodactylus neodreptus (East side of Sierra de Bahoruco) was described by Schwartz (1965) from a single specimen and synonymized with E. audanti (sensu stricto) by Hedges (1996). Other species morphologically related to E. audanti are E. parabates (Sierra de Neiba) and E. haitianus (Cordillera Central). The taxonomy of the E. abbotti species group is still controversial, since some populations show morphological, genetic and bioacoustic distinctions enough to be considered as different taxa. One of these populations was discovered by one of the authors (MR) not far away from the city of Santo Domingo, on the southeastern slope of the Cordillera Central, showing an intermediate morphology between E. haitianus and E. audanti.

\section{OBJECTIVES}

-To describe the above mentioned population as a new species.

-To provide comparative information on other related taxa of the Eleutherodactylus abbotti species group.

\section{MATERIALS AND METHODS}

External morphology. Measurements were taken with digital calipers (accuracy $0.01 \mathrm{~mm}$ ) under a dissecting microscope Leica MZ-12. Most of the morphological measurements follow Watters et al. (2016), except for the hand length that was taken from the distal border of palmar tubercle to the tip of third finger disc (instead of fourth). This decision was made because in most species finger III is longer than IV (not the opposite condition). We are using tympanum width (horizontally taken like Watters et al., 2016) and also the tympanum height (vertically measured) in our data set for Eleutherodactylus, considering that the shape of this structure is variable among species and the tympanum is not always round enough to be characterized by only one diameter. The diameter of the digital discs was measured if discs looked turgid and not deformed by specimen dehydration.

Molecular phylogeny. DNA was extracted either from liver or leg muscle following the protocol of Ivanova et al. (2006). To eliminate potential PCR-inhibiting contaminants, the tissue samples were incubated for $14 \mathrm{hrs}$ at $4^{\circ} \mathrm{C}$ in $200 \mu \mathrm{L}$ low PBS buffer $(20 \mu \mathrm{L}$ PBS in $180 \mu \mathrm{L}$ of water) before overnight digestion with the vertebrate lysis buffer at $56^{\circ} \mathrm{C}$. After extraction, the DNA was eluted in $50 \mu \mathrm{L}$ TE buffer. A fragment of the mitochondrial 16S rRNA gene was amplified in an Eppendorf Mastercycler ${ }^{\circledR}$ pro using the following protocol: initial denaturation for $2 \mathrm{~min}$ at $94^{\circ} \mathrm{C}$; followed by 40 cycles with denaturation for $35 \mathrm{~s}$ at $94^{\circ} \mathrm{C}$, hybridization for $35 \mathrm{~s}$ at $48.5^{\circ} \mathrm{C}$, and elongation for $60 \mathrm{~s}$ at $72^{\circ} \mathrm{C}$; final elongation for $10 \mathrm{~min}$ at $72^{\circ} \mathrm{C}$. The reaction mix for each sample contained $1 \mu \mathrm{L}$ DNA template, $14 \mu \mathrm{L}$ water, $2.5 \mu \mathrm{L}$ PCR-buffer, $1 \mu \mathrm{L} 25$ $\mathrm{mM} \mathrm{MgCl}, 4 \mu \mathrm{L} 2.5 \mathrm{mM}$ dNTPs (Invitrogen), $0.5 \mu \mathrm{L}$ (containing 2.5 units) Taq Polymerase (PeqLab), and $1 \mu \mathrm{L}$ of each primer (forward: L2510, 5'-CGCCTGTTTATCAAAAACAT-3'; reverse: H3056, 5'-CCGGTCTGAACTCAGATCACGT-3'; Eurofins MWG Operon). 
Phylogenetic relationships were estimated using both maximum likelihood (ML) and Bayesian methods. We determined an appropriate model of sequence evolution and model parameters using Kakusan 4.0 (Tanabe, 2011), resulting in the J2 + Gamma model and the GTR + Gamma model for the ML tree and the Bayesian tree, respectively, based on the Akaike information criterion. ML estimation was performed using Treefinder (Jobb et al., 2004) and their robustness was validated using bootstrap analysis with 1000 replications. Bayesian estimation to confirm the ML topology was conducted using MrBayes version 3.1.2 (Ronquist and Huelsenbeck, 2003). We performed 10 million generations of Markov chain Monte Carlo (MCMC) with a sampling frequency of 1000. The MCMC convergence was verified using Tracer 1.7 (Rambaut et al., 2018) and the first 2000 trees were discarded as burn-in, with the remaining samples being used to estimate the tree topology.

Bioacoustic analysis. Calls were recorded with a Marantz PMD 661 digital sound recorder and a Sennheiser ME 66 microphone. Bioacoustic data were obtained with the software Raven Pro 1.5 (Cornell Laboratory of Bioacoustics). Figures were generated with the software BatSound 5.1 (Pettersson Elektronic AB (C1996-1999) using a FFT of 512 points and Hanning windows. Bioacoustical terms and general methods follow Köhler et al. (2017). For this group of frogs we are considering that advertisement call is either (1) a train of short notes periodically repeated as a tight unit (as typical of most species) or (2) repetitive longer signals which are well spaced each other along a period of time and not assembled as tight trains (the case of E. parabates).

The following abbreviations are used to refer to institutions and collections: MNHNSD, Museo Nacional de Historia Natural "Prof. Eugenio de Jesús Marcano", Santo Domingo, República Dominicana; PRRD, field numbers of Proyecto Anfibios Amenazados y Cambio Climático en República Dominicana (specimens deposited at MNHNSD); SMF, Senckenberg, Forschungsinstitut und Naturmuseum, Frankfurt, Germany. Specimens other than type series are listed in Appendix 1. Geographic coordinates are in WGS84 (World Geodetic System 1984).

\section{Eleutherodactylus geitonos sp. nov.}

Figures: external morphology, 1A-C and 2A-B; phylogeny, 3; holotype, 4; vomerine odontophores, 5; sonagrams and oscilograms, 6A, G; distribution, 7; habitat, 8.

Holotype. MNHNSD 23.3438 (original field number PRRD 670), adult male from $3.8 \mathrm{~km} \mathrm{NW}$ of El Corte Nuevo (18²9'17.29'N; 70¹6’38.49'W), $1084 \mathrm{~m}$ above the sea level, Cambita Garabitos Municipality, San Cristóbal Province, southeastern slope of Cordillera Central, Dominican Republic, collected by Luis M. Díaz, Cristian Marte and Marcos Rodríguez on February 9, 2014.

Paratypes $(\mathrm{n}=20)$. Males ( $\mathrm{n}=10)$ : SMF 103894, MNHNSD 23.3443, MNHNSD 23.3448-51, SMF 103895-96, MNHNSD 23.3456-57 (original field numbers PRRD 661, 665, 671-74, 681-82, 683-684, respectively). Females (n=10): SMF 10397-98, MNHNSD 23.3440-42, 23.3444-3447, 23.3453 (original numbers PRRD 642-43, 662-64, 666-69, 680), same collecting data as holotype.

Diagnosis. A small species (maximum SVL in males $12.8 \mathrm{~mm}$, in females $15.8 \mathrm{~mm}$ ) of the Eleutherodactylus abbotti species group of the E. auriculatus species series (sensu Hedges et al., 2008; confirmed by Padial et al., 2014) as supported by morphological and genetic data (Figs. 1-3). It requires the closest comparison with $E$. haitianus but also with $E$. audanti and related species (E. melatrigonum, E. notidodes, and E. parabates; see Discussion). 
From those species, E. geitonos sp. nov. differs in lacking a pectoral fold and by having a small vocal sac that is not distinctively folded when deflated. Eleutherodactylus geitonos sp. nov. and $E$. haitianus are both very small frogs and the former, on average, has an even smaller size than the latter (see Table I). The new species has more distinctive digital discs than E. haitianus (third finger disc $3.1-4.0 \%$ of SVL, $\overline{\mathrm{x}}=3.4 \%$, vs. $1.8-2.9 \%, \overline{\mathrm{x}}=2.4 \%$, in E. haitianus); a relatively longer snout (15-17\% of SVL, vs. 12-15\% in E. haitianus), and a pair of incomplete dorsolateral folds (vs. dorsolateral rows of tubercles in E. haitianus, with very prominent ones at the suprascapular level). Eleutherodactylus geitonos sp. nov. lacks the pattern of dark spots that E. haitianus typically has on belly and throat, and yellow coloration is more extended to ventral surfaces of males than in the latter species (Fig. 2). Advertisement calls of E. geitonos sp. nov. are long trains of notes like in E. haitianus (Fig. 6), but in the latter species' call, the introductory note is long, somewhat frequency modulated, while a distinctive call introductory note is not present in E. geitonos sp. nov. From $E$. audanti and closely related taxa, the new species also differs in being much smaller (see Table I); in E. audanti toe $\mathrm{V}$ is longer than toe III, but in the new species these toes are of similar size or III $>\mathrm{V}$. Eleutherodactylus parabates is also a larger species (up to $24 \mathrm{~mm} \mathrm{SVL}$; Schwartz and Henderson, 1991) with stocky body and advertisement calls consisting of long whistles.

Diagnosis (Español). Especie de pequeño tamaño (LHC máxima en los machos, $12.8 \mathrm{~mm}$; hembras, $15.8 \mathrm{~mm}$ ) del grupo de especies E. abbotti, de la serie E. auriculatus (sensu Hedges et al, 2008; confirmado por Padial et al., 2014), como sugieren los datos morfológicos y genéticos (Figs. 1-3). Requiere una estrecha comparación con E. haitianus, pero también con E. audanti y las especies afines a ésta (E. melatrigonum, E. notidodes, y E. parabates; véase Discusión). De todas estas especies E. geitonos sp. nov. se diferencia por la carencia de pliegue pectoral y por tener un saco vocal pequeño que no se pliega apreciablemente cuando está desinflado. Tanto Eleutherodactylus geitonos sp. nov. como E. haitianus son ranas muy pequeñas y el nuevo taxón tiene una talla promedio aún más reducida que la segunda especie (Tabla I). La nueva especie tiene los discos digitales de las manos más desarrollados que E. haitianus (tercer dedo $3.1-4.0 \%$ de la LHC, $\bar{x}=3.4 \%, v s .1 .8-2.9 \%, \bar{x}=2.4 \%$, en E. haitianus); un hocico relativamente más largo (15-17\% de la LHC vs. 12-15\%, en E. haitianus); un par de pliegues dorsolaterales incompletos ( $v s$. hileras dorsolaterales de tubérculos en E. haitianus, siendo los de la región supraescapular muy prominentes). Eleutherodactylus geitonos sp. nov. no tiene un manchado conspicuo en la garganta y el vientre como típicamente ocurre en Eleutherodactylus haitianus, y la coloración amarilla está más extendida sobre las superficies ventrales de los machos que en la segunda especie (Fig. 2). Las llamadas de anuncio de E. geitonos sp. nov. son largos trenes de notas como en E. haitianus (Fig. 5), pero en la última especie la nota introductoria de cada llamada es larga y con cierta modulación de frecuencia, mientras que no existe una nota introductoria diferenciada de esta manera en E. geitonos sp. nov. De $E$. audanti y taxones cercanos, la especie nueva se diferencia por ser mucho más pequeña (Tabla I); en E. audanti el dedo V del pie es más largo que el III, pero en la nueva especie estos dedos tienen una longitud similar ó III $>$ V. Eleutherodactylus parabates es una especie de mayor tamaño (hasta 24 mm LHC; Schwartz and Henderson, 1991), con un cuerpo robusto y llamadas de anuncio consistentes en prolongados silbidos. 


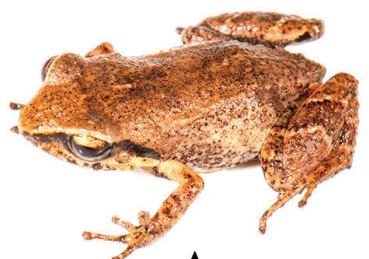

A
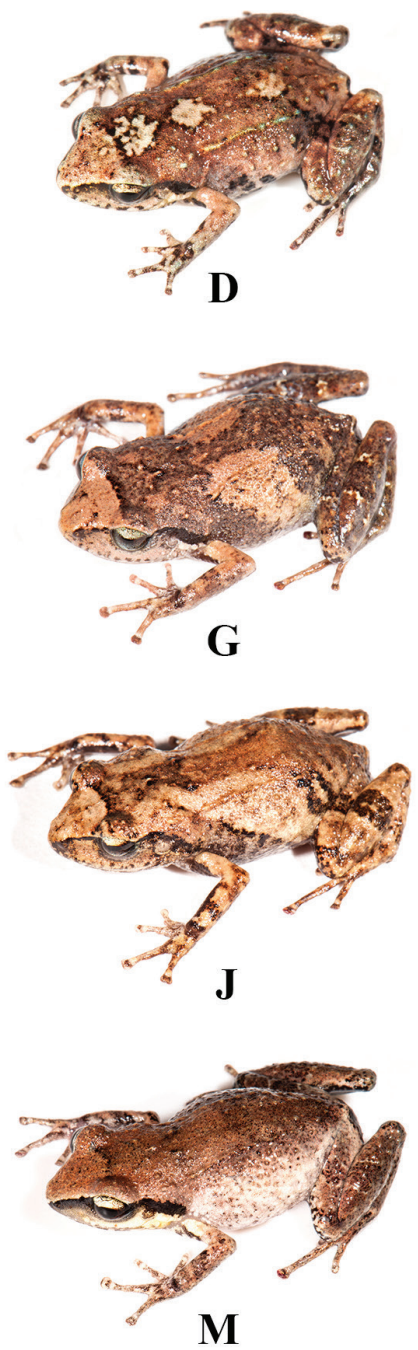
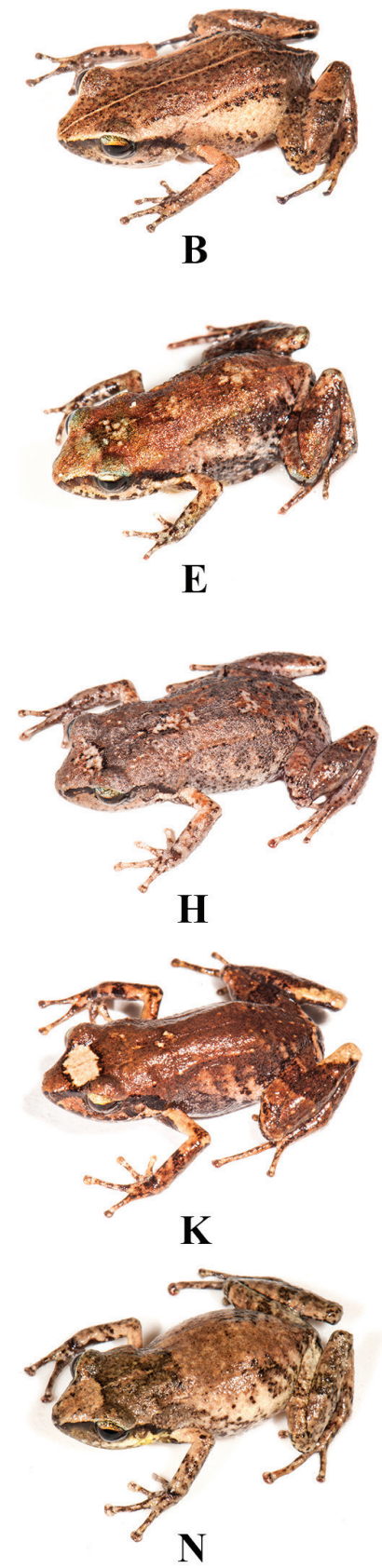
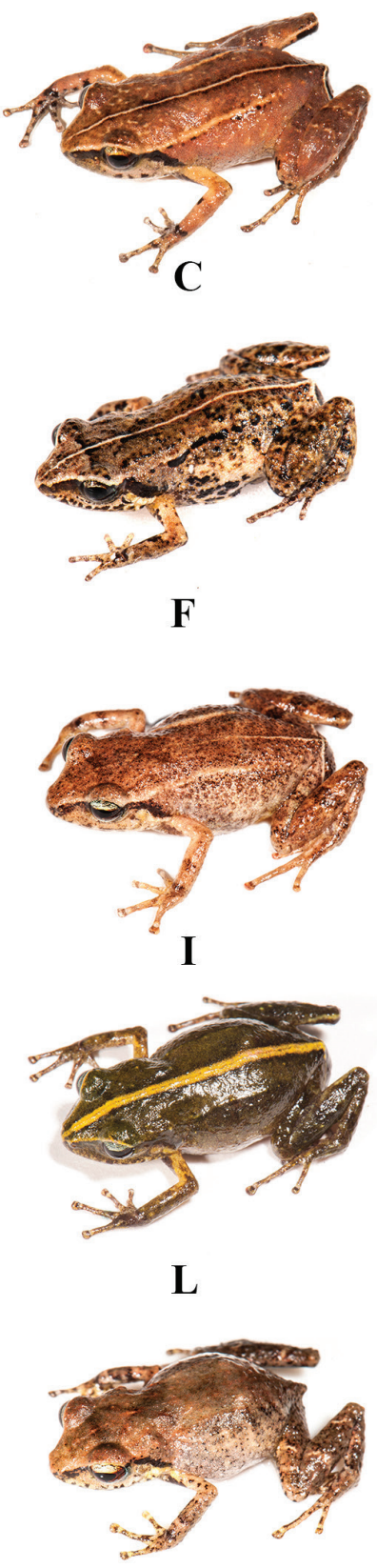

$\mathbf{O}$

Figure 1. Related frogs of the Eleutherodactylus abbotti species group. Eleutherodactylus geitonos sp. nov. (A-C) pattern variation in paratypes MNHNSD 23.3456 (A), 23.3440 (B), and 23.3444 (C). Eleutherodactylus haitianus (D-F), pattern variation in MNHNSD 23.3474 (D), 23.3473 (E), 23.3465 (F), surroundings of La Pirámide, Valle Nuevo, La Vega, Cordillera Central. Eleutherodactylus audanti (G-L), pattern variation in MNHNSD 23.2579(G) and 23.2577 (H), Loma del Toro, Sierra de Bahoruco; MNHNSD 23.2515 (I), MNHNSD 23.2496 (J), MNHNSD 23.2512 (K) and 23.2511 (L), Zapoten, Sierra de Bahoruco. Eleutherodactylus melatrigonum (M), MNHNSD 23.3459, $6 \mathrm{~km} \mathrm{~S}$ of Constanza (old road), La Vega, Cordillera Central. Eleutherodactylus notidodes $(\mathrm{N})$, road to Pinos del Edén, Sierra de Neiba. Eleutherodactylus audanti (neodreptus?), MNHNSD 23.2568, Cachote, Bahoruco. Photos: Luis M. Díaz. 


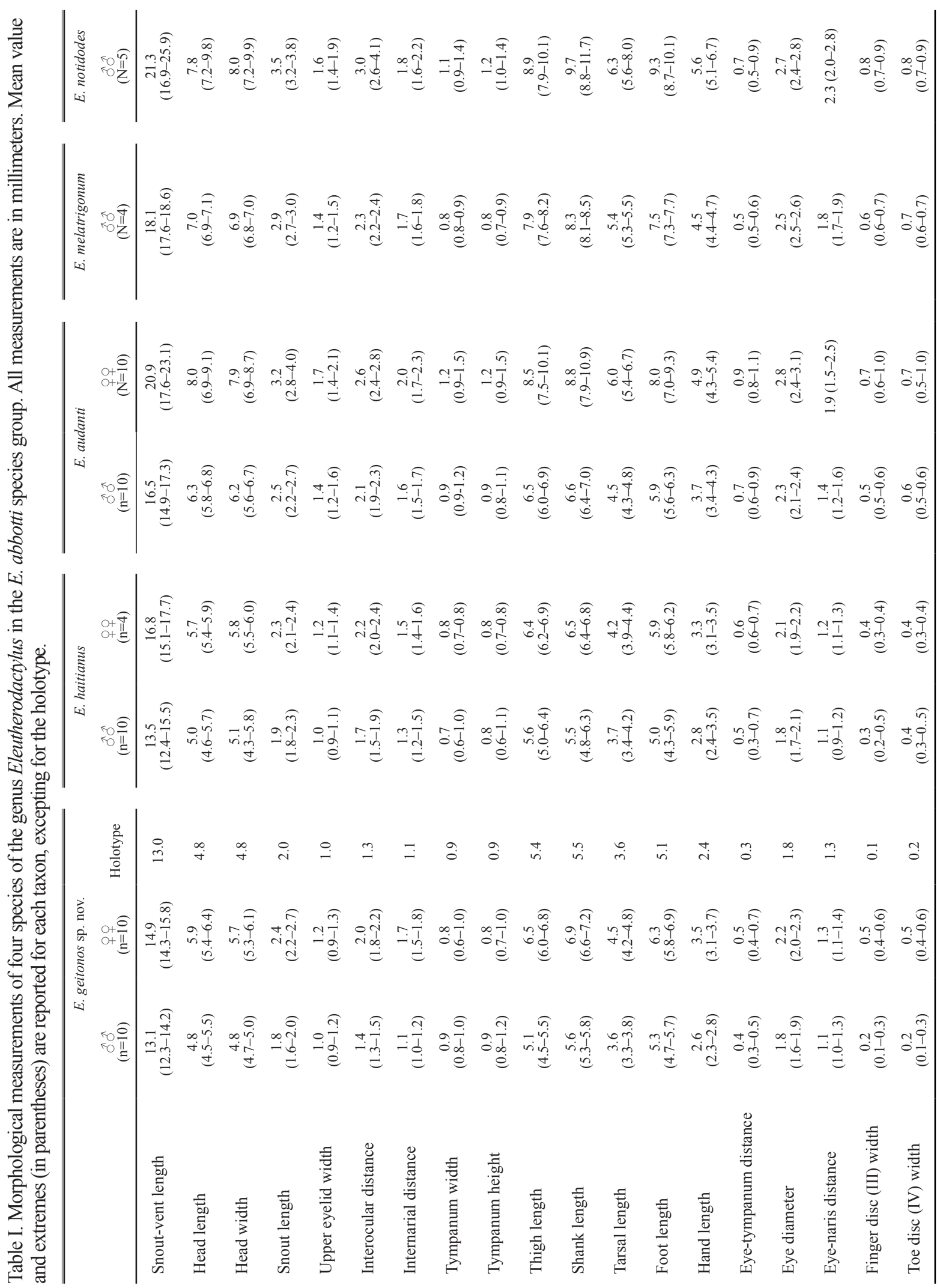


Description. Head as wide as long, head width $90-100 \%(\overline{\mathrm{x}}=97 \%)$ of head length; snout subacuminate in dorsal view and in profile, slightly overlapping the lower jaw; snout length $38-44 \%(\bar{x}=41 \%)$ of head length; nostrils oval, weakly protuberant, directed laterally, and separated by a distance equivalent to $26-32 \%(\overline{\mathrm{x}}=29 \%)$ of head width; canthus rostralis straight in dorsal view and rounded in profile; loreal region gradually sloping to the labial border; lips not flared; interorbital distance $32-39 \%(\bar{x}=36 \%)$ of the head width; upper eyelid $48-66 \%$ $(\bar{x}=58 \%)$ of the interorbital distance; eyelid skin with very small granules; loreal area smooth; tympanum small, superficial, rounded, with distinct annulus, $25-50 \%(\overline{\mathrm{x}}=37 \%)$ of eye diameter; supratympanic fold conspicuously pigmented with black; 1 to 3 postrictal tubercles aligned to form a light area below the posterior half of the supratympanic fold; choanae $51-63 \%(\bar{x}=58 \%)$ of the third finger disc diameter, oval, lateral in position, partially hidden by the palatal shelf of the maxillary arch; vomerine odontophores very small, bearing 7 to 8 teeth, $1 \frac{1 / 4}{4}$ times the length of each choana, situated in a diagonal position between the choanae and separated from each other by a distance equivalent to half their own length (Fig. 5); tongue oval, 3/4 not adherent to floor of mouth; external vocal sac of males subgular, small, round shaped, and not distinctively folded when deflated; vocal slits present.

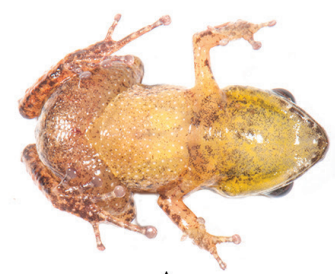

A

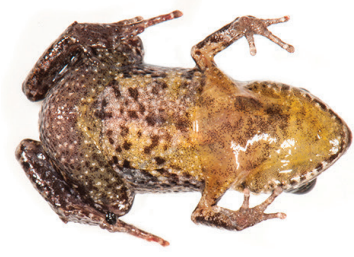

D
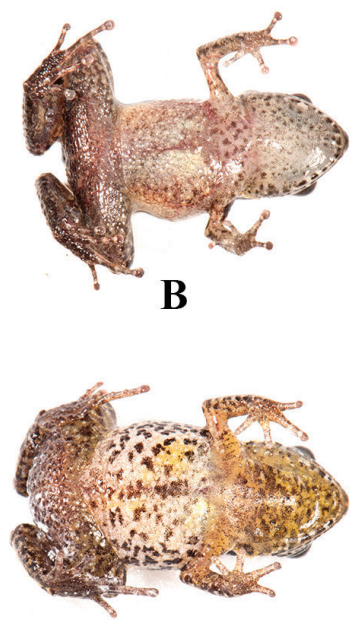

$\mathbf{E}$
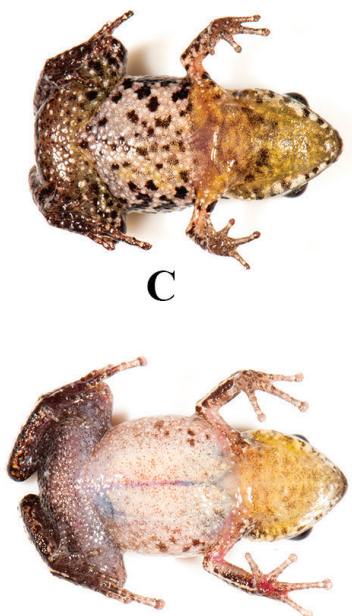

$\mathbf{F}$

Figure 2. Ventral views of Eleutherodactylus geitonos sp. nov. (A-B), paratopotypes MNHNSD 23.3454 (A) and MNHNSD 23.3453 (B); E. haitianus (C-E), MNHNSD 23.3474 (C), 23.3473 (D), and 23.3465 (E), surroundings of La Pirámide, Valle Nuevo, La Vega; E. melatrigonum (F), MNHNSD 23.3459, $6 \mathrm{~km} \mathrm{~S}$ of Constanza (old road), La Vega, Cordillera Central. Photos: Luis M. Díaz.

Dorsal skin with scattered granules, and fully covered with glandular pores; dorsolateral tubercles aligned and fused to form incomplete folds; lower surface of flanks areolate. A well evident supratympanic gland, but other glands not conspicuously swollen. Venter areolate. Inner surface of thigh areolate. Palmar tubercle rounded to oval, smooth, $13 / 4$ times longer than thenar tubercle; supernumerary palmar tubercles absent; subarticular tubercles of fingers rounded and moderately prominent. Finger length order: III $>$ IV $>$ II $>$ I; digital discs moderately enlarged and somewhat expanded laterally, the disc on finger III 1.5-1.6 times wider than the phalange width at base and its diameter is $51-85 \%(\bar{x}=62 \%)$ of tympanum width; discs are larger in the two outer fingers but slightly decrease in size on disc II and I. 
Heels without enlarged tubercles; inner metatarsal tubercle two times longer than the slightly conical outer metatarsal tubercle; supernumerary tubercles absent; subarticular tubercles rounded to oval and moderately prominent in profile. Toes without defined lateral ridges or basal webbing; circumferential groove bordering the distal half of toe pad; heels separated or barely touching each other when flexed legs are held at right angles to sagittal plane; toes length order: IV $>$ V $\geq$ III $>$ II $>$ I. Hand length $20-25 \%(\bar{x}=23 \%)$ of SVL; foot length $38-44 \%$ $(\bar{x}=42 \%)$ of SVL; thigh length $38-48 \%(\bar{x}=43 \%)$ of SVL; shank length $42-51 \%(\bar{x}=46 \%)$ of SVL; tarsal length $28-39 \%(\bar{x}=31 \%)$ of SVL. Measurements are summarized in Table I.

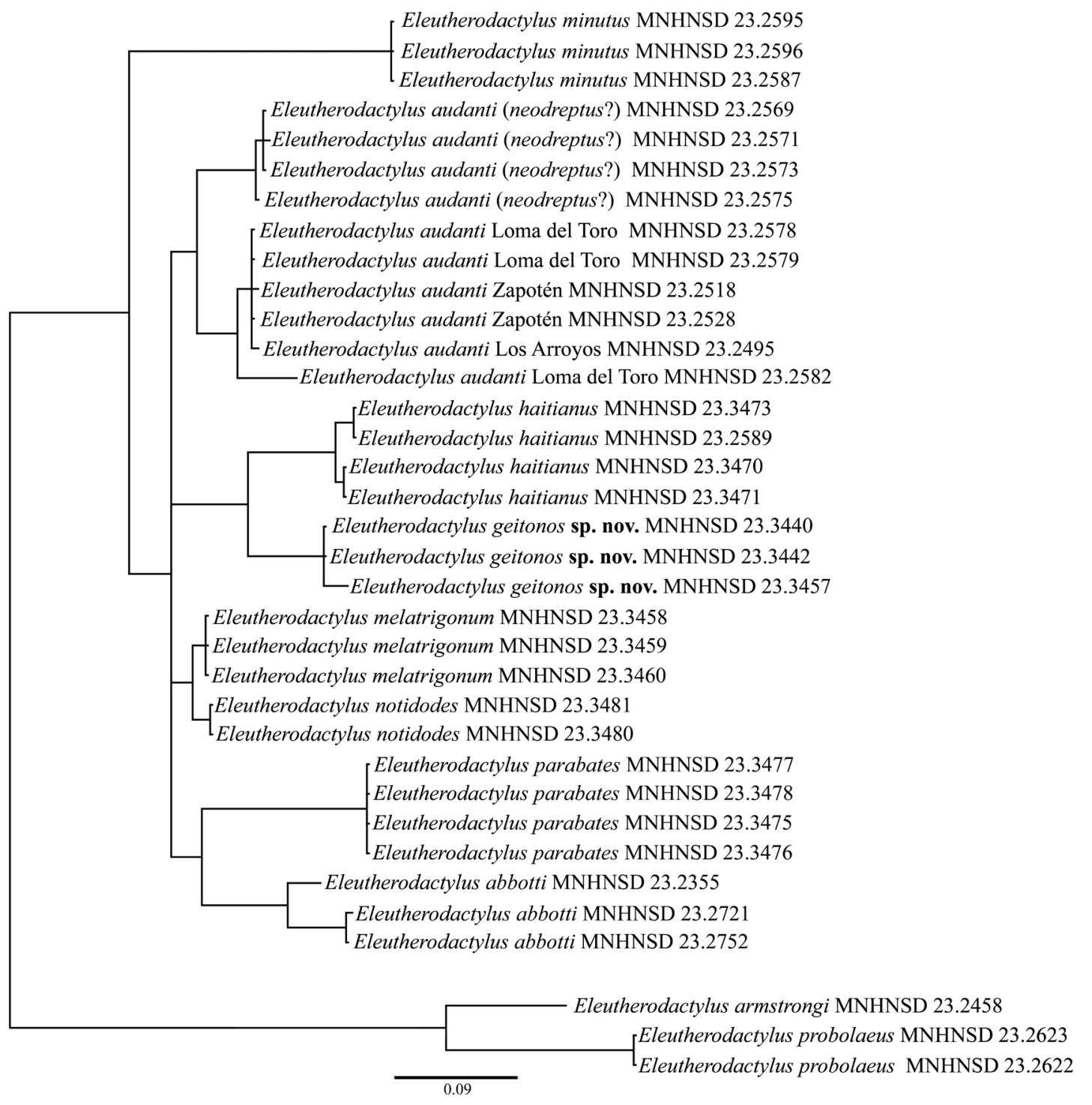

Figure 3. Phylogenetic tree of frogs in the Eleutherodactylus abbotti species group, obtained from a Bayesian analysis of DNA sequences of the $16 \mathrm{~S}$ rRNA gene. Species names are specified along with voucher specimens' collection numbers. Specimens and localities are listed in Appendix 1. The tree is rooted with E. minutus (subgenus Eleutherodactylus), E. armstrongi, and E. probolaeus (subgenus Euhyas). 


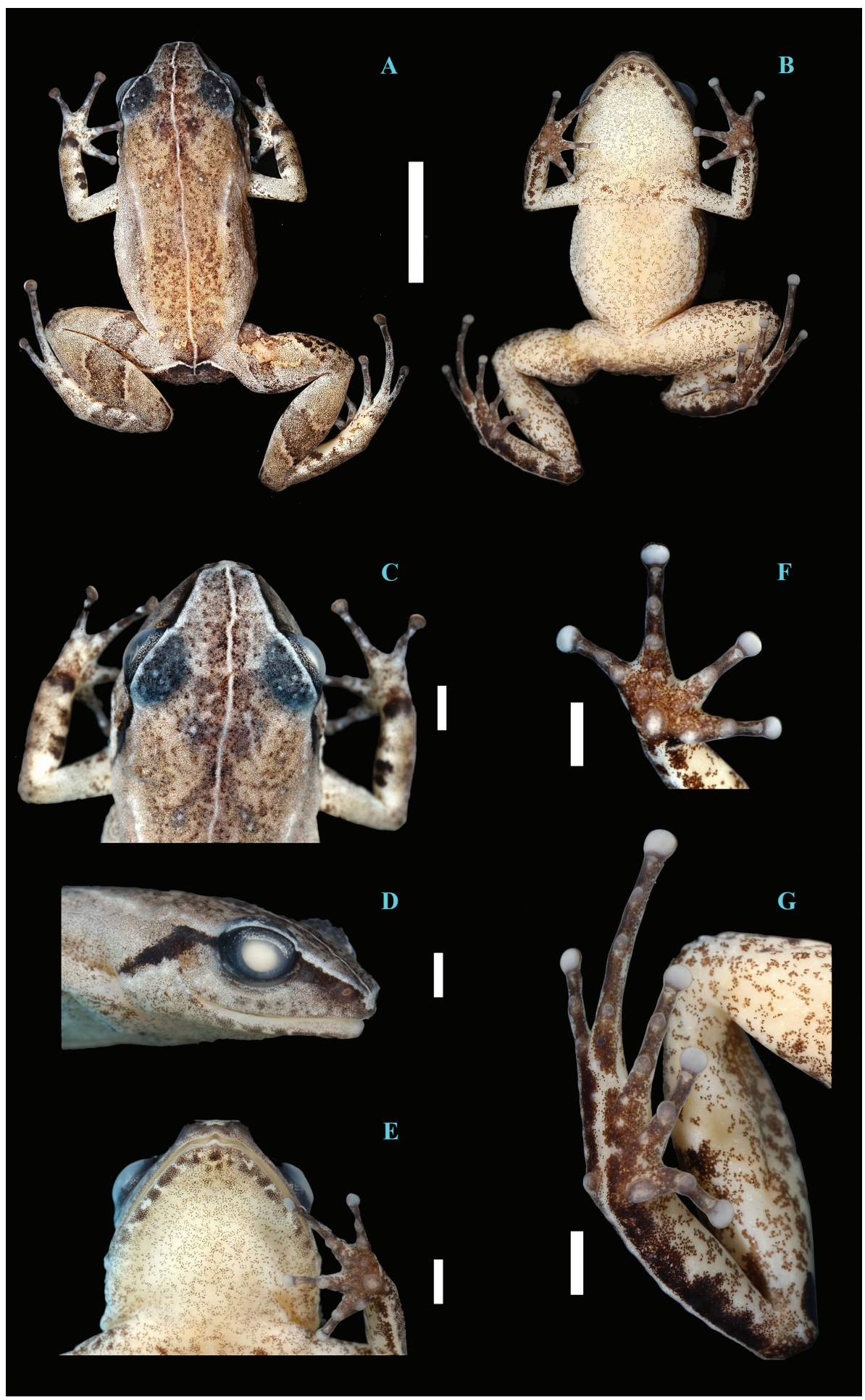

Figure 4. Eleutherodactylus geitonos sp. nov., holotype male MNHNSD 23.3438, showing external morphology. Preserved specimen photographed one year after collection. A: overall body in dorsal view (scale bar $=5 \mathrm{~mm}$ ); B: overall body in ventral view (bar=5 mm); C: head in dorsal view; D: head in profile; E: throat; F: palmar view; G: plantar view (scale bars=1 mm). Photos: Gunther Köhler. 


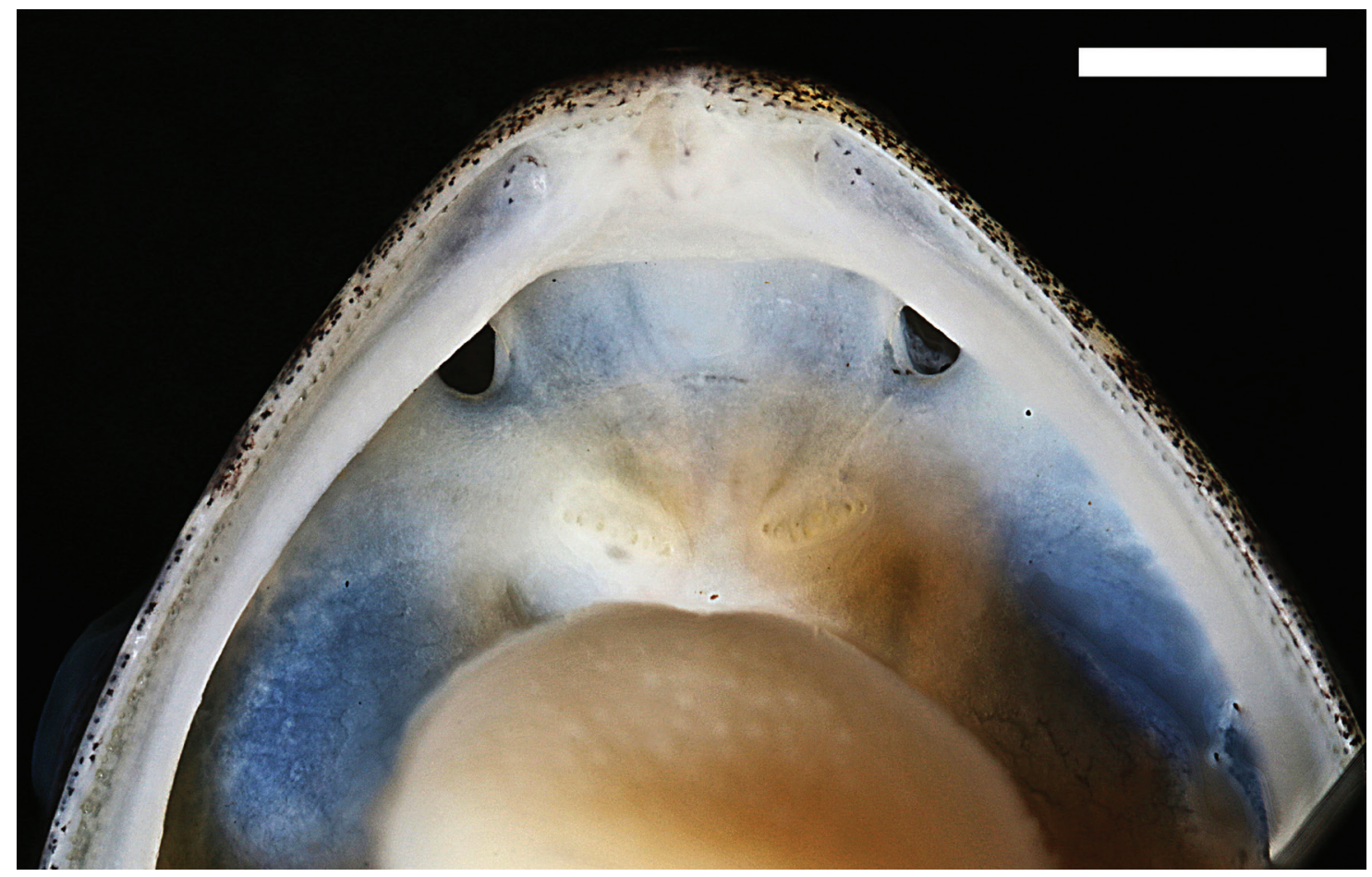

Figure 5. Eleutherodactylus geitonos sp. nov., preserved paratype MNHNSD 23.3440, showing the vomerine odontophores and the choanae (scale bar=1 mm). Photos: Arne Schulze.

Color in alcohol of the holotype (three years after collection): dorsum brownish-gray with a dark chevron-like suprascapular pattern (Fig. 4). Yellow tonalities were not preserved. Some whitish tubercles are defined in the suprascapular area. Interocular bar very evident. A white sagittal hairline is extended along middorsum to the vent, where it bifurcates onto the inner surface of hind limbs and plantar surface. A similar line is also present on inner surfaces of forelimbs and hands. Inner surface of fore- and hind limbs, distinctively darken. Snout, anterior to interocular bar, paler than dorsum but darker at both sides of the sagittal hairline. Snout, in dorsal view, and the external edge of eyelids with a whitish outline. Thigh, shank, and tarsus, crossed by wide, pale outlined dark bands. Vent area and proximal thigh inner surface defining a dark triangle, outlined above by the bifurcations of the sagittal hairline. Forelimbs with two incomplete antebrachial dark bars. Arms distinctively paler than dorsum. Dorsum somewhat stippled. The dorsolateral folds slightly paler than middorsum. Ventral surface, including throat, belly and hind legs, finely stippled on a white background. Chest with some dark spots. Mandibles with dark blotches. Lores crossed by a dark stripe from the tip of snout to eye. Supratympanic fold black, extended to forelimbs; area under this fold and behind tympanum distinctively paler.

Color in life: dorsum brownish tan, brown to reddish brown, with variably highlighted yellowish tones on arms. Hind limbs with broad brown bands outlined with a paler tonality. Supratympanic fold very dark, almost black, extended to forelimbs. Area below the supratympnic fold and behind tympanum usually yellow. Lores crossed by a dark brown stripe, which is continuous with the dark lower-half of the iris. Eleutherodactylus geitonos sp. nov., is a polymorphic species with different dorsal patterns. A dorsal, chevron-like brown figure is more or less defined at the level of forelegs in many individuals (including the holotype). 
An interocular bar is usually present, often with a brown extension onto the suprascapular chevron (Fig. 1A). Snout, anterior to interocular bar, slightly paler than dorsum. Flanks with the same color as dorsum or with a broad and distinctive cream area (Fig. 1B). Some individuals with narrow, dorsolateral orange stripes (Fig. 1C). A whitish to tan middorsal hairline is evident in most individuals. Belly and throat typically yellow in males, but grayish in young individuals and in females.

Advertisement calls and bioacoustics comparison. Eleutherodactylus geitonos sp. nov. and $E$. haitianus are the two species in the E. abbotti species group with the highest note- repetition rate and, correspondingly, the shortest note periods. Also, both species have the highest pitched calls as expected by their smaller sizes. Table II compares the call parameters of $E$. geitonos sp. nov. with E. haitianus, but also with those of E. audanti and closely related species that share an advertisement call pattern consisting of a train of notes.

Advertisement calls of Eleutherodactylus geitonos sp. nov. have 13-44 notes $(\overline{\mathrm{x}}=26.1)$. Notes are clicks that increase in intensity gradually within each call. Calls usually end abruptly (Fig. 6G). Call period is very variable, 14-75.8 ( $\overline{\mathrm{x}}=33.1)$ seconds; note duration, 11-29 $(\overline{\mathrm{x}}=17.4)$ milliseconds; note period, $124-183(\overline{\mathrm{x}}=146)$ milliseconds; notes rise time, $1-4(\overline{\mathrm{x}}=1.8)$ milliseconds; notes repetition rate $6.2-9.1(\bar{x}=7.1)$ notes/second. The dominant frequency is $5.0-5.6(\overline{\mathrm{x}}=5.3) \mathrm{kHz}$. Note's frequency is somewhat modulated or have no modulation. In E. haitianus, the calls usually start with a distinctive note that is $68-115(\overline{\mathrm{x}}=90)$ milliseconds long, followed by shorter signals of $12-28(\overline{\mathrm{x}}=15)$ milliseconds. First note duration is not distinctively differentiated in E. geitonos sp. nov. as shown in Table II, and has the lowest intensity of the call (Fig. 6G). Typically, notes of E. haitianus gradually decrease intensity at the end of each call (Fig. 6H).

Eleutherodactylus melatrigonum and E. notidodes emit the longest calls of the group, with some of them almost lasting one minute (Table II). In E. notidodes there were few calls in the upper limit of $E$. audanti, barely overlapping in call duration. These two species also showed lower dominant frequencies than $E$. audanti, very likely due to their somewhat larger sizes and maybe the influence of some environmental factors. The only measured E. melatrigonum has shorter notes than E. notidodes.

Eleutherodactylus parabates produces long, single noted whistles (Fig. 6F) instead of the long trains of clicking notes of the other species. This species is sympatric with $E$. notidodes and an as-yet undescribed species related to $E$. audanti. They all vocalize in the same area but inhabiting different microhabitats. Eleutherodactylus parabates is the only species that wasn't included in Table II due to its very different call pattern. We only had one male available for measurements, but many were heard and the whistling nature of vocalizations was referred by Schwartz (1966) in the species' original description. Calls have a duration of 215-267 $(\overline{\mathrm{x}}=233 ; \mathrm{n}=15)$ milliseconds, call period: 411-461 $(\overline{\mathrm{x}}=433 ; \mathrm{n}=14)$ milliseconds, dominant frequency: $2.6-2.8(\bar{x}=2.7 \mathrm{kHz} ; \mathrm{n}=15) \mathrm{kHz}$, and a repetition rate of 141 calls/minute. Calls rise time: $130-180(\bar{x}=149, n=15)$ milliseconds. Each call has a slight ascendant modulated period in the first 20-30 milliseconds of its duration. 
A
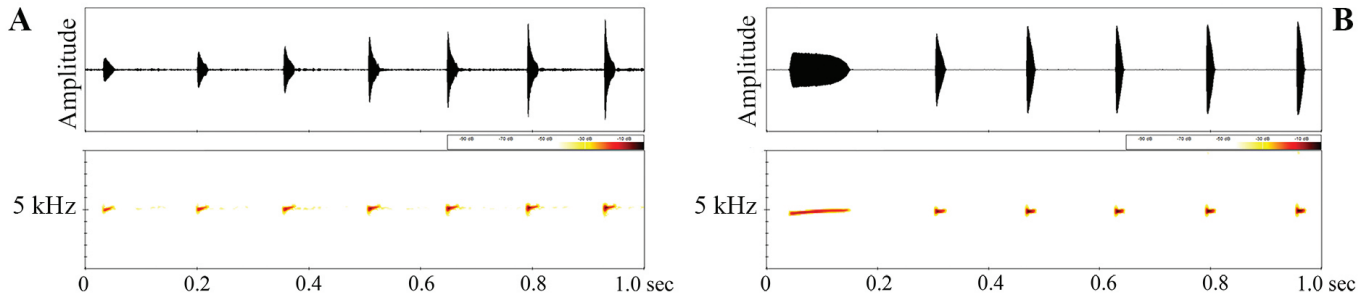

C
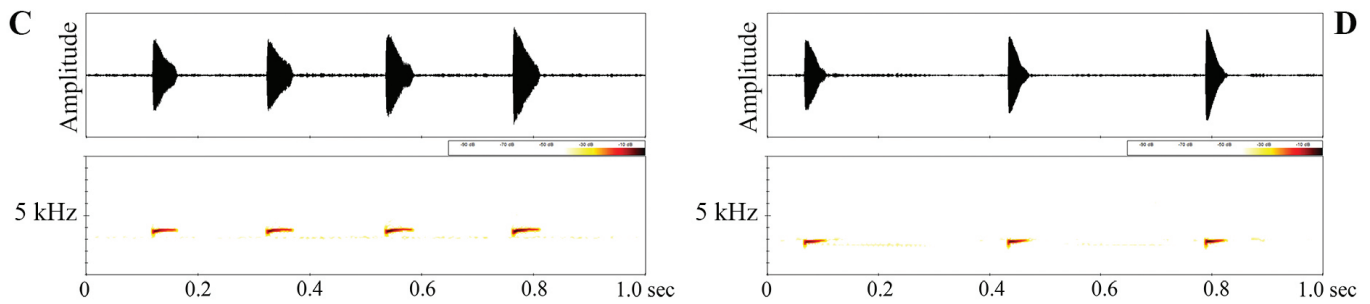

$\mathbf{E}$
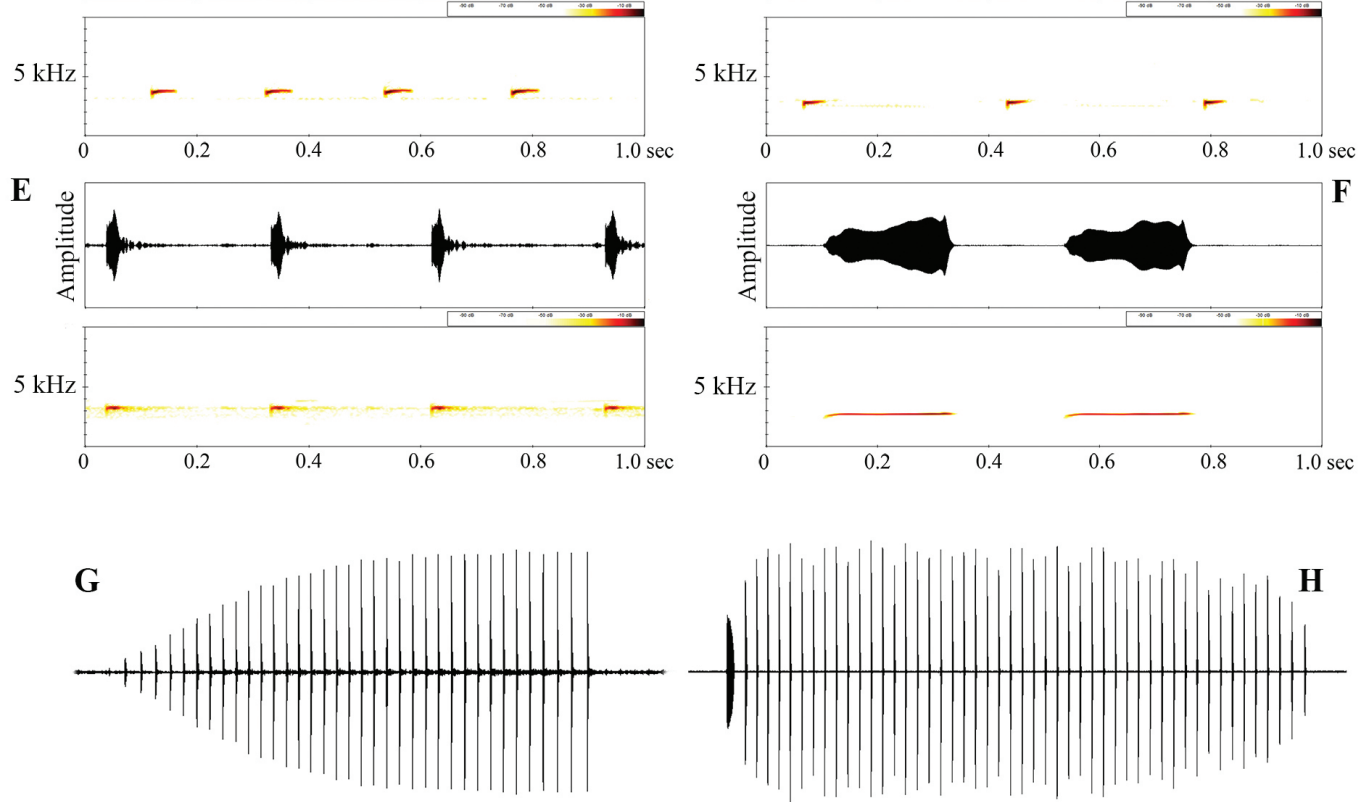

$5 \mathrm{sec}$.
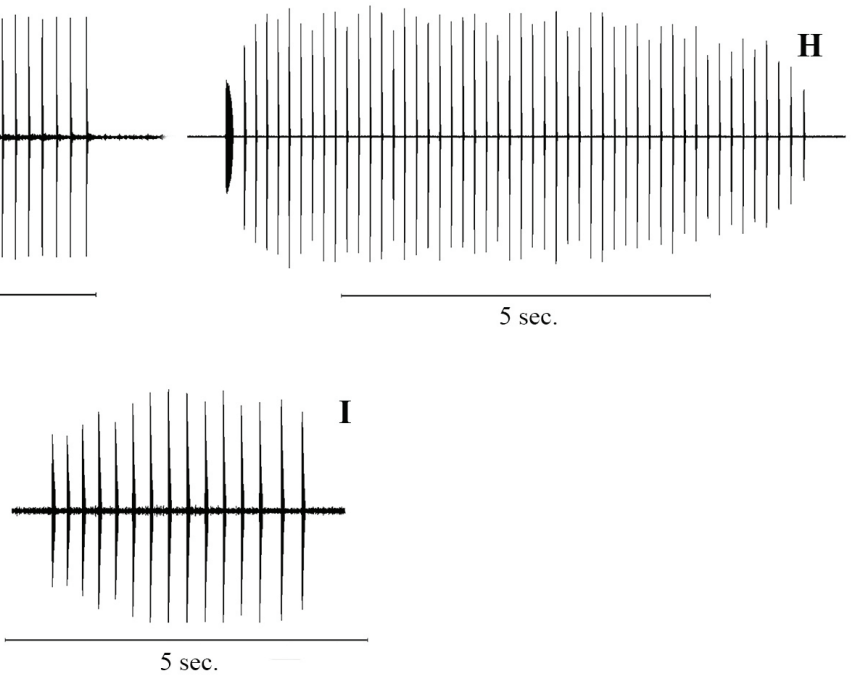

Figure 6. Sonagrams and oscilograms of advertisement calls of some related frogs of the E. abbotti species group. (A) First seven notes in a call of Eleutherodactylus geitonos sp. nov. from the type locality $\left(16^{\circ} \mathrm{C}\right)$; (B) First six notes in a call of $E$. haitianus from La Pirámide, Valle Nuevo, Cordillera Central $\left(12^{\circ} \mathrm{C}\right) ;(\mathrm{C})$ E. audanti, from Loma del Toro, Bahoruco $\left(11^{\circ} \mathrm{C}\right) ;(\mathrm{D})$ E. notidodes, from road to Pinos del Edén, Sierra de Neiba $\left(20^{\circ} \mathrm{C}\right)$; (E) E. melatrigonum, from $\sim 6 \mathrm{~km} \mathrm{~S}$ of Constanza $\left(16^{\circ} \mathrm{C}\right)$; (F) E. parabates, from Sierra de Neiba $\left(10^{\circ} \mathrm{C}\right) ;(\mathrm{G})$ temporal pattern of a whole call of E. geitonos sp. n., same data as A; $(\mathrm{H})$ E. haitianus (same data as B); (I) E. audanti (same data as C). 
Table II. Acoustic data for the advertisement calls of four related frogs of the Eleutherodactylus abbotti species group.

\begin{tabular}{|c|c|c|c|c|c|}
\hline & $\begin{array}{l}\text { E. geitonos sp. nov. } \\
\qquad(\mathrm{n}=5)\end{array}$ & $\begin{array}{l}\text { E. haitianus } \\
\qquad(\mathrm{n}=3)\end{array}$ & $\begin{array}{l}\text { E. audanti } \\
\qquad(\mathrm{n}=3)\end{array}$ & $\begin{array}{l}\text { E. melatrigonum } \\
\qquad(\mathrm{n}=1)\end{array}$ & $\begin{array}{l}\text { E. notidodes } \\
\qquad(\mathrm{n}=4)\end{array}$ \\
\hline Call duration (s) & $\begin{array}{c}3.6 \\
(2.0-6.5) \\
\mathrm{n}=50\end{array}$ & $\begin{array}{c}4.9 \\
(3.6-5.8) \\
\mathrm{n}=30\end{array}$ & $\begin{array}{c}5.5 \\
(3.1-10.2) \\
\mathrm{n}=30\end{array}$ & $\begin{array}{c}51.2-51.5 \\
\mathrm{n}=2\end{array}$ & $\begin{array}{c}27.8 \\
(9.5-46.5) \\
\mathrm{n}=40\end{array}$ \\
\hline Call period (s) & $\begin{array}{c}33.1 \\
(14-75.8) \\
\mathrm{n}=50\end{array}$ & $\begin{array}{c}37.6 \\
(13.6-53.7) \\
n=28\end{array}$ & $\begin{array}{c}13.7 \\
(6.3-34.7) \\
n=30\end{array}$ & 79.7 & $\begin{array}{c}36.9 \\
(12.9-61.6) \\
n=40\end{array}$ \\
\hline Notes per call & $\begin{array}{c}26.1 \\
(13-44) \\
n=50\end{array}$ & $\begin{array}{c}31.3 \\
(19-45) \\
\mathrm{n}=30\end{array}$ & $\begin{array}{c}15.5 \\
(5.0-27.0) \\
\mathrm{n}=30\end{array}$ & $\begin{array}{c}179-189 \\
n=2\end{array}$ & $\begin{array}{c}114.5 \\
(34-179) \\
n=40\end{array}$ \\
\hline First note duration (ms) & $\begin{array}{c}19.0 \\
(11-29) \\
\mathrm{n}=50\end{array}$ & $\begin{array}{c}92.3 \\
(68-115) \\
n=30\end{array}$ & - & - & - \\
\hline Note duration (ms) & $\begin{array}{c}17.4 \\
(11-29) \\
\mathrm{n}=500\end{array}$ & $\begin{array}{c}15.7 \\
(12-28) \\
n=298\end{array}$ & $\begin{array}{c}33.6 \\
(20-61) \\
\mathrm{n}=297\end{array}$ & $\begin{array}{c}22.6 \\
(20-26) \\
\mathrm{n}=34\end{array}$ & $\begin{array}{c}41.9 \\
(32-52) \\
n=400\end{array}$ \\
\hline Note rise time (ms) & $\begin{array}{c}1.8 \\
(1-4) \\
\mathrm{n}=500\end{array}$ & $\begin{array}{c}2.7 \\
(1-5) \\
\mathrm{n}=300\end{array}$ & $\begin{array}{c}2.5 \\
(1-8) \\
\mathrm{n}=300\end{array}$ & - & $\begin{array}{c}2.4 \\
(2-4) \\
\mathrm{n}=400\end{array}$ \\
\hline Note period (ms) & $\begin{array}{c}146 \\
(124-183) \\
n=498\end{array}$ & $\begin{array}{c}161 \\
(122-206) \\
n=300\end{array}$ & $\begin{array}{c}271 \\
(221-402) \\
n=300\end{array}$ & $\begin{array}{c}287 \\
(255-337) \\
\mathrm{n}=33\end{array}$ & $\begin{array}{c}252 \\
(186-329) \\
n=400\end{array}$ \\
\hline Notes repetition rate (notes/s) & $\begin{array}{c}7.1 \\
(6.2-9.1) \\
\mathrm{n}=50\end{array}$ & $\begin{array}{c}6.4 \\
(4.0-8.2) \\
\mathrm{n}=30\end{array}$ & $\begin{array}{c}3.7 \\
(2.9-3.9) \\
\mathrm{n}=30\end{array}$ & $\begin{array}{l}3.5-3.7 \\
\mathrm{n}=2\end{array}$ & $\begin{array}{c}4.1 \\
(3.5-5.2) \\
\mathrm{n}=40\end{array}$ \\
\hline Dominant frequency $(\mathrm{kHz})$ & $\begin{array}{c}5.3 \\
(5.0-5.6) \\
n=50\end{array}$ & $\begin{array}{c}4.9 \\
(4.7-5.6) \\
n=30\end{array}$ & $\begin{array}{c}3.7 \\
(3.4-3.8) \\
n=30\end{array}$ & $\begin{array}{c}3.3 \\
\mathrm{n}=2\end{array}$ & $\begin{array}{c}2.9 \\
(2.3-3.0) \\
n=40\end{array}$ \\
\hline
\end{tabular}

Distribution. The new species is only known from the type locality (Fig. 7). However, frogs with similar call patterns and habitats have been recorded at Rancho Arriba (Sierra de Ocoa; San José de Ocoa Province), El Valle de Dios (Parque Nacional Loma La Humeadora; San Cristobal Province), and Los Guayuyos (near Parque Nacional Luis Quin; Peravia Province). Additional surveys will confirm the geographic distribution of the new species in those potential localities and nearby areas.

Etymology. The specific epithet is from the ancient Greek yeit $\omega v$, geitôn, meaning a neighbor, in allusion to the proximity of the type locality to the city of Santo Domingo.

Ecological notes. At the type locality (Fig. 8), the habitat of E. geitonos sp. nov. is a mesophilous cloud forest ("bosque latifoliado nublado"; as described by Hager and Zanoni, 1993: 60), with patches of palm forests (Prestoea montana) locally known as "manaclares". The area has been modified by human activities along with some deforestation, cattle farming and agriculture. The new species was heard calling either inside the forest or along trail-sides covered by dense vegetation. The new frog is primarily associated with the grass stratum. Males start vocalizing activity at dusk and the type series was collected after 19:00 hours, either on plants or on the ground in an area of less than $600 \mathrm{~m}^{2}$. About twenty calling males were detected there. Temperature was $16^{\circ} \mathrm{C}$ and the relative humidity $94 \%$. Calling males were either found on the ground or, very often, perched on ferns. Males were hidden in fern's trunk crevices, protected inside dead fern fronds, or among the leaves of other nearby plants. Calling sites were less than one meter high. Females were found on the leaf litter. Other species of Eleutherodactylus recorded with E. geitonos sp. nov. were E. abbotti, E. auriculatoides, and E. inoptatus. 


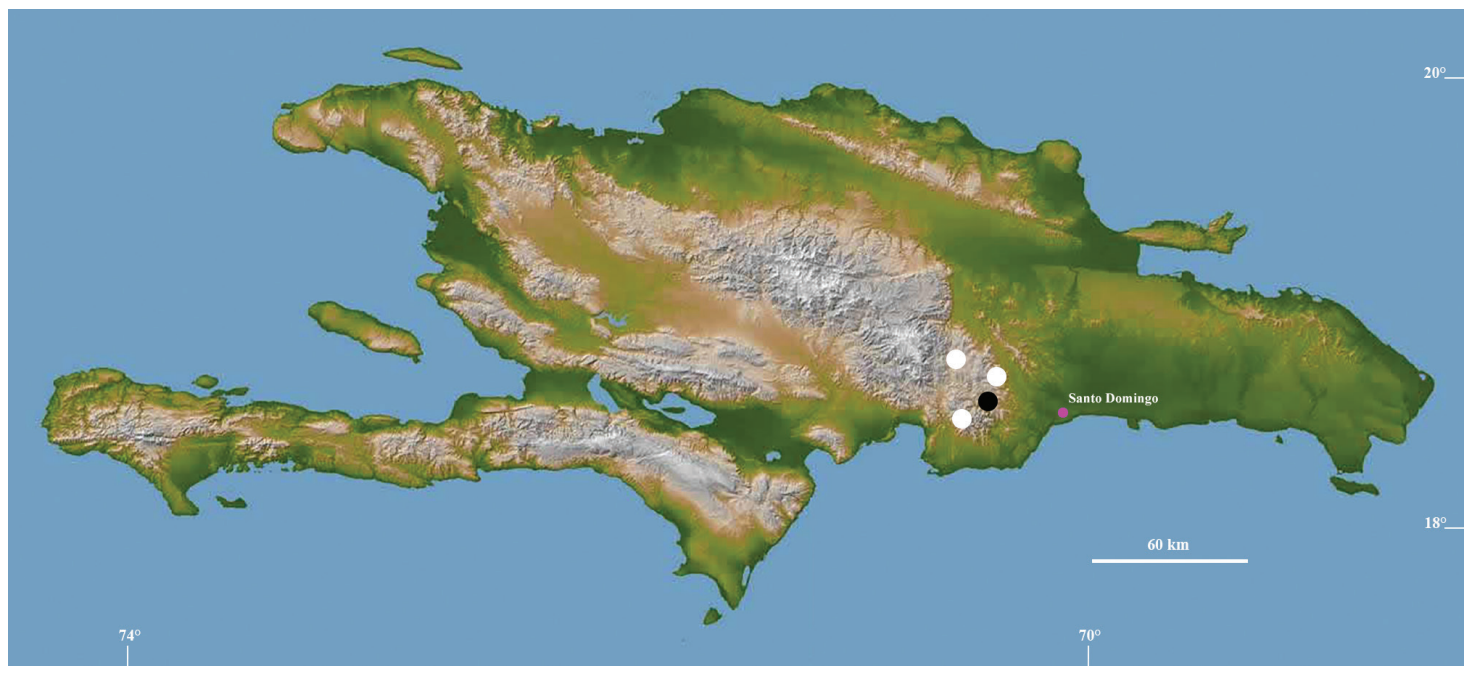

Figure 7. Map of Hispaniola showing the type locality (black dot) and potential distribution (white dots) of the new species Eleutherodacylus geitonos, as mentioned in text.

\section{DISCUSSION}

The obtained phylogeny (Fig. 3) agree with the general results of Hedges et al. (2008) and Padial et al. (2014). It confirms the sister relationships of E. geitonos sp. nov. with $E$. haitianus and its inclusion in the E. abbotti species group. The tree also show that the sampled population of E. audanti from Cachote, Eastern side of Sierra de Bahoruco, is genetically distinct from those of the western side (Loma del Toro, Zapotén, and Los Arroyos), which might indicate that E. neodreptus should be resurrected. To complicate this issue even more, Schwartz and Henderson (1991) mapped, and Hedges (1996) later discussed that the distribution of E. audanti extends to the East of Bahoruco reaching the same area of E. neodreptus. This is a new field of research since E. neodreptus was described from only one specimen. As such, additional morphological, genetic and bioacoustic comparisons using a larger set of data from multiple localities have to be conducted to clarify the taxonomic status of this controversial group of cryptic frogs.

Our genetic data barely separate $E$. notidodes and E. melatrigonum; the two species probably represent a single taxon ( $E$. notidodes) that has a wide distribution in the north paleoisland. Although Hedges et al. (2008) elevated the two taxa to species level, only E. notidodes was included in their phylogeny and the taxonomic status of E. melatrigonum was inferred based on described morphology (Schwartz, 1966) and its allopatric distribution. Padial et al. (2014) did not include E. notidodes and E. melatrigonum in their analysis, but recognized them as different species within the E. abbotti species group. We are aware that our phylogeny is limited to the $16 \mathrm{~S}$ rRNA gene, and thus constitutes a matrilineal genealogy only; however, this gene has proven to be very useful for species delimitations in amphibians (ie: Vences et al., 2005; Vences et al., 2008; Maya-Soriano et al., 2012; Grosjean et al., 2015; Rockney et al., 2015; Ohler and Nicolas, 2017). 

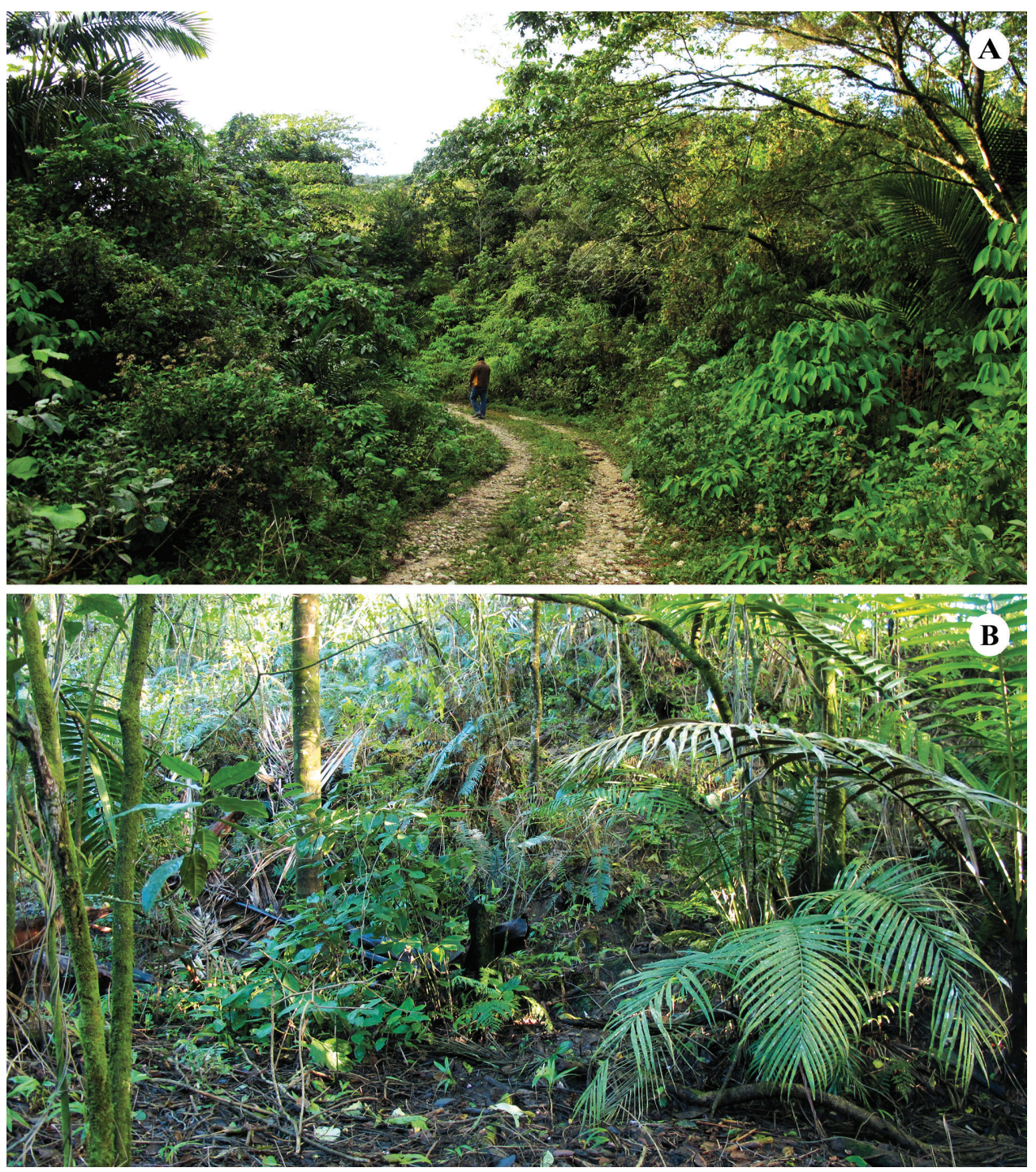

Figure 8. Habitat of Eleutherodactylus geitonos sp. nov. (A) trail crossing the surroundings of the type locality; (B) a detail of the new species microhabitat. Photos: Cristian Marte.

Eleutherodactylus geitonos sp. nov. is readily distinguished from E. abbotti, a sympatric but larger species (up to $25 \mathrm{~mm}$ SVL; Schwartz and Henderson, 1991) that lacks defined dorsolateral folds, has advertisement calls (described by Galvis et al. 2016) consisting of heterogeneous notes which are rhythmically uttered in complex assemblages, the body exhibits different color patterns and the genetic relationship with the new species is more distant (as shown in Fig. 3). Eleutherodactylus pituinus is a completely different species that do not offer confusion with the new species; it reach 29 mm SVL (Schwartz and Henderson, 1991), lack dorsolateral folds, has dark brown concealed surfaces on legs, a prominently stippling dorsal pattern, more conspicuous subarticular tubercles, and very distinctive advertisement calls. 
Ecological differences also distinguish $E$. geitonos sp. nov. and E. haitianus. In contrast with the new species, $E$. haitianus typically occurs in high elevation valleys (usually $\geq 2000 \mathrm{~m}$ a.s.1.) having highland pine forests (Pinus occidentalis) and the edges of mesophilous forests (see descriptions by Hager and Zanoni, 1993:69). Frogs are usually associated to the grass stratum, particularly in those habitats dominated by the grass Danthonia domingensis (Poaceae), which is locally known as pajón. Males call either hidden in these plants or they climb to get exposed among the thin leaves, although they can be found calling from other grasses, low bushes and ferns (Henderson and Powell, 2009).

\section{ACKNOWLEDGMENT}

We are grateful to Nils Navarro, Kenia Ng, Eveling Gavot and Miguel A. Landestoy for their assistance during field work. Many thanks to Linda Mogk (Senckenberg, Forschungsinstitut und Naturmuseum Frankfurt, Germany), for obtaining the genetic data and her kind assistance in the lab. Arne Schulze helped us with specimen photographs. We acknowledge Celeste Mir and Carlos Suriel (Museo de Historia Natural of Santo Domingo) for their kind support and the work space at the Museum. This paper is an outcome of the project Anfibios Amenazados y Cambio Climático en República Dominicana (Endangered Amphibians and Climate Change in Dominican Republic), financed by Ministerio de Educación Superior, Ciencia y Tecnología, FONDOCYT 2008-1-A-102, of Dominican Republic, and its conclusion was also supported by the project Taxonomía de algunos grupos zoológicos de Cuba y del Caribe, con acciones de capacitación especializada, divulgación, y educación ambiental (Museo Nacional de Historia Natural de Cuba). Our gratitude to Grupo Jaragua (Santo Domingo) for the administrative and logistic support of the Project, with especial thanks to Yvonne Arias, Yolanda León, and Miguel Abreu. Also to the authorities of Museo Nacional de Historia Natural de Cuba, Agencia de Medio Ambiente (CITMA, Cuba), and Sociedad Cubana de Zoología for supporting the Cuban participants of the Project. LMD wishes to express his gratitude to the University of Würzburg (particularly to Michael Schmid, Wolfgang Feichtingeri, and Claus Steinlein), and the Belgian Focal Point to the Global Taxonomy Initiative (especially to Yves Samyn) for providing the photographic equipment. Sound recording equipment and Raven Pro was kindly donated by the Cornell Lab of Ornithology, and we especially wish to thank Greg Budney, John Fitzpatrick, and Eduardo Iñigo for their extraordinary support over several years. Thanks to Kraig Adler, Martha Muñoz, Robert Murphy and Shannan Yates, for their very welcomed comments and suggestions on different versions of manuscript.

\section{LITERATURE CITED}

Galvis, P. A., V. Zaffaroni, S. J. Sánchez-Pacheco and M. Rada. 2016. The advertisement calls of three Eleutherodactylus species from Hispaniola (Anura: Eleutherodactylidae). Bioacoustics, DOI: 10.1080/09524622.2016.1260053.

Grosjean, S., A. Ohler, Y. Chuaynkern, C. Cruaud and A. Hassanin. 2015. Improving biodiversity assessment of anuran amphibians using DNA barcoding of tadpoles. Case studies from Southeast Asia. Comptes Rendus Biologies, 338: 351-361.

Hager, J. and T. A. Zanoni. 1993. La vegetación natural de la República Dominicana: una nueva clasificación. Moscosoa, 7: 39-81.

Hedges, S. B. 1996. The Hispaniolan frog Eleutherodactylus neodreptus Schwartz (Anura: Leptodactylidae) is a synonym of E. audanti Cochran. Caribbean Journal of Science, 32: 248 . 
Hedges, S. B., W. E. Duellman, and M.P. Heinicke. 2008. New World direct developing frogs (Anura: Terrarana): Molecular phylogeny, classification, biogeography, and conservation. Zootaxa, 1737: 1-182.

Henderson, R. W., and R. Powell. 2009. Natural History of West Indian reptiles and amphibians. University Press of Florida, 493 pp.

Ivanova, N. V., J. De Waard and P. D. N. Hebert. 2006. An inexpensive, automation-friendly protocol for recovering high-quality DNA. Molecular Ecology Notes, 6: 998-1002.

Jobb, G., A. von Haeseler, and K. Strimmer. 2004. TREEFINDER: a powerful graphical analysis environment for molecular phylogenetics. BMC Evolutionary Biology, 4:18.

Köhler, J., M. Jansen, A. Rodríguez, P. J. R. Kok, L. F. Toledo , M. Emmrich, F. Glaw, C. F. B. Haddad, M. O. Rödel, and M. Vences. 2017. The use of bioacoustics in anuran taxonomy: theory, terminology, methods and recommendations for best practice. Zootaxa, 4251(1): 1-124. doi: 10.11646/zootaxa.4251.1.1.

Maya-Soriano, M. J., W. V. Holt and R. E. Lloyd. 2012. Biobanked amphibian samples confirmed to species level using 16S rRNA DNA barcodes. Biopreserv. biobank, 10: 22-28.

Ohler, A. and V. Nicolas. 2017. Which frog's legs do froggies eat? The use of DNA barcoding for identification of deep frozen frog legs (Dicroglossidae, Amphibia) commercialized in France. European Journal of Taxonomy, 271: 1-19.

Padial, J. M., T. Grant and D. R. Frost. 2014. Molecular systematics of terraranas (Anura: Brachycephaloidea) with an assessment of the effects of alignment and optimality criteria. Zootaxa, 3825 (1): 001-132.

Rambaut A., A. J. Drummond, D. Xie, G. Baele and M. A. Suchard. 2018. Tracer v1.7, Available from http://beast.community/tracer.

Rockney, H. J., C. Ofori-Boateng, N. Porcino and A. D. Leaché. 2015. A comparison of DNA barcoding markers in West African frogs. African Journal of Herpetology, 64 (2): 135-147.

Ronquist, F. and J. P. Huelsenbeck. 2003. Mrbayes 3: Bayesian phylogenetic inference under mixed models. Bioinformatics, 19: 1572-1574.

Schwartz, A. 1965. A new species of Eleutherodactylus (Amphibia: Leptodactylidae) from the Sierra de Baoruco, Dominican Republic. Proceedings Biological Society of Washington, 78: $165-168$.

Schwartz, A. 1966. The relationships of four small Hispaniolan Eleutherodactylus (Leptodactylidae). Bulletin Museum of Comparative Zoology, 133: 369-399.

Schwartz, A. and R. W. Henderson. 1991. Amphibians and Reptiles of the West Indies. University of Florida Press, Gainesville, 720 pp.

Tanabe, A. S. 2011. Kakusan4 and Aminosan: two programs for comparing nonpartitioned, proportional and separate models for combined molecular phylogenetic analyses of multilocus sequence data. Molecular Ecology Notes, 11: 914-921. 
Vences, M., M. Thomas, A. van der Meijden, Y. Chiari and D. R. Vieites. 2005. Comparative performance of the 16S rRNA gene in DNA barcoding of amphibians. Frontiers in Zoology, 2005, 2:5 doi:10.1186/1742-9994-2-5.

Vences, M., Y. Chiari, M. Teschke, R-D. Randrianiaina, L. Raharivololoniaina, P. Bora, D. R. Vieites and F. Glaw. 2008. Which frogs are out there? A preliminary evaluation of survey techniques and identification reliability of Malagasy amphibian. A Conservation Strategy for the Amphibians of Madagascar. Monografie del Museo Regionale di Scienze Naturali di Torino, XLV (2008): 233-252.

Watters, J. L., S. T. Cummings, R. L. Flanagan and C. D. Siler. 2016. Review of morphometric measurements used in anuran species descriptions and recommendations for a standardized approach. Zootaxa, 4072 (4): 477-495.

\section{APPENDIX I}

\section{SPECIMENS EXAMINED FOR COMPARISONS AND GENETIC PHYLOGENY}

Eleutherodactylus abbotti (n=3).- MNHNSD 23.2721, 23.2752, Aguas Negras, Bahoruco; 23.2355, Cachote, Bahoruco.

Eleutherodactylus armstrongi (n=1)._- MNHNSD 23.2458, Polo, Sierra de Bahoruco, Barahona.

Eleutherodactylus audanti (n=93).- MNHNSD 23.2480-2494, 23.2496-2549, Zapoten, Bahoruco. MNHNSD 23.2550-64, 23.2577-2582, Loma del Toro, Bahoruco. MNHNSD 23.2565-67, Las Abejas, Bahoruco.

Eleutherodactylus audanti (neodreptus?, n=9). - MNHNSD 23.2568-76, Cachote, Sierra de Bahoruco, Bahoruco.

Eleutherodactylus haitianus ( $\mathrm{n}=13$ ).- MNHNSD 23.3464-74, Valle Nuevo, Cordillera Central, La Vega Province; MNHNSD 23.3482-83, Parque Nacional José del Carmen Ramírez, San Juan de la Maguana.

Eleutherodactylus melatrigonum (n=6).- MNHNSD 23.3458-63, 6 km S of Constanza, La Vega. Eleutherodactylus minutus ( $\mathrm{n}=15)$ - - MNHNSD 23.2585-97, Valle Nuevo, Cordillera Central, La Vega Province; MNHNSD 23.2607-08, Idem; MNHNSD 23.2598-99, Casabito, Ébano Verde, La Vega.

Eleutherodactylus notidodes ( $\mathrm{n}=8$ ).- MNHNSD 23.2600-2606, 23.3480-81, Sabana del Silencio, Sierra de Neiba, Bahoruco Province.

Eleutherodactylus parabates $(\mathrm{n}=6)$.- MNHNSD 23.3475-79, Sabana del Silencio, Sierra de Neiba, Bahoruco.

Eleutherodactylus pituinus (n=1).- MNHNSD 23.2584, $\sim 6 \mathrm{~km} \mathrm{~S} \mathrm{of} \mathrm{Constanza,} \mathrm{La} \mathrm{Vega.}$ 